Finanse, Rynki Finansowe, Ubezpieczenia nr 3/2017 (87), cz. 2

DOI: $10.18276 /$ frfu. $2017.87 / 2-14$

s. $161-168$

\title{
Znaczenie ksiąg rachunkowych w określaniu podstawy opodatkowania w podatku dochodowym
}

\author{
Jolanta Iwin-Garzyńska*
}

\begin{abstract}
Streszczenie: Cel artykulu - Ukazanie istoty ksiąg rachunkowych w obliczaniu podstawy opodatkowania w podatku dochodowym na tle teorii podatku.

Metodologia badania - Wykorzystano metodę analizy literatury oraz krytycznej analizy norm prawa podatkowego i rachunkowego, zapisów ustawy ordynacja podatkowa, ustawy o rachunkowości, ustawy o podatku dochodowym od osób prawnych.

Wynik - Dzięki przeprowadzonym badaniom przedstawiono definicje podatku w świetle nauki finansów i rachunkowości oraz kategorii rzetelności ksiąg rachunkowych.

Oryginalność/wartość - Wartością dodaną publikacji jest oryginalne przedstawienie podatkowego aspektu ksiąg rachunkowych i ich znaczenia dla wymiaru podatku dochodowego.
\end{abstract}

Słowa kluczowe: księgi rachunkowe, podatek dochodowy, rzetelność

\section{Wprowadzenie}

Podatki są stałą części życia każdego przedsiębiorstwa i stałym elementem nauki finansów, prawa finansowego, a także nauki i praktyki rachunkowości. Na tym tle rysuje się znaczenie podatków w nauce finansów przedsiębiorstwa (Iwin-Garzyńska, 2010, s. 48-49) oraz konieczność podkreślenia znaczenia ksiąg rachunkowych w określaniu podstawy opodatkowania podatkiem dochodowym przedsiębiorstw. Waga problemu wynika z zapisu art. 217. Konstytucji RP, zgodnie z którym ,nakładanie podatków, innych danin publicznych, określanie podmiotów, przedmiotów opodatkowania i stawek podatkowych, a także zasad przyznawania ulg i umorzeń oraz kategorii podmiotów zwolnionych od podatków następuje w drodze ustawy" (Konstytucja..., 1997).

Rzetelne ustalenie wysokości podstawy opodatkowania przedsiębiorstwa wymaga stosowania odpowiednich narzędzi, do których należą niewątpliwie księgi podatkowe, a wśród nich księgi rachunkowe.

* prof. dr hab. Jolanta Iwin-Garzyńska, Uniwersytet Szczeciński, Wydział Nauk Ekonomicznych i Zarządzania, e-mail: jiwin@wneiz.pl 
Celem artykułu jest ukazanie istoty ksiąg rachunkowych w obliczaniu podstawy opodatkowania w podatku dochodowym. W wyniku przeprowadzonych badań przedstawiono sedno definicji podatku w świetle nauki finansów i rachunkowości oraz kategorii rzetelności ksiąg rachunkowych.

\section{Istota ksiąg rachunkowych}

Ustalenie wysokości podstawy opodatkowania w podatku dochodowym zgodnie ze stanem faktycznym wymaga odpowiednich narzędzi ewidencyjnych. Jednym z tych narzędzi są księgi podatkowe, czym określa się wachlarz urządzeń ewidencyjnych, które przedstawiono w Ordynacji podatkowej ${ }^{1}$.

Do pojęcia księgi podatkowe zalicza księgi rachunkowe, podatkowe księgi przychodów i rozchodów, ewidencje i rejestry. Do prowadzenia tych urządzeń w celach podatkowych zobowiązani są podatnicy, płatnicy oraz inkasenci. W przedstawionej regulacji widoczny jest brak precyzji. O ile nie budzi wątpliwości pojęcie ksiąg rachunkowych ani podatkowych ksiąg przychodów i rozchodów, to ewidencje i rejestry są na tyle zróżnicowane, że w praktyce o zaliczeniu danych urządzeń do ksiąg podatkowych często decydują dopiero szczegółowe przepisy prawa podatkowego, a nieraz także praktyka.

Księgi podatkowe są dowodami o szczególnej mocy. Ich prowadzenie jest niezwykle istotne przy określaniu podstawy opodatkowania. Są wyjątkowe, ponieważ będąc dokumentami o charakterze stricte prywatnym mają taką samą moc dowodową jak dokumenty publiczne. Przysługuje im ponadto domniemanie prawdziwości, jednak nie jest ono niewzruszalne. Zgodnie z zapisami art. 193 Ordynacji podatkowej stanowią one dowód tego, co zostało w nich zapisane, ale pod warunkiem, że były prowadzone rzetelnie i w sposób niewadliwy. Owa rzetelność polega na zgodności zapisów z rzeczywistością, natomiast niewadliwość oznacza prowadzenie księgi zgodnie z odpowiednimi przepisami prawa (tzw. prawidłowość formalna).

Księgi rachunkowe są uregulowane w Ustawie z 29 września 1994 roku o rachunkowości. Uchwalenie tej ustawy wiązało się z rozgraniczeniem prawa bilansowego od prawa podatkowego.

Szczególna i uprzywilejowana pozycja ksiąg rachunkowych jako dowodów nie jest absolutem. Zgodnie z zapisami art. 193 Ordynacji podatkowej, księgi stanowią dowód tego, co z nich wynika, pod warunkiem, że są prowadzone rzetelnie i w sposób niewadliwy. Oznacza to, że księgi stracą ten status, gdy zostanie stwierdzona ich nierzetelność lub wadliwość. Pierwszą z odmian nieprawidłowości, jaką dotknięte mogą być księgi, jest nierzetelność (Dzwonkowski, Zgierski, 2006, s. 828).

Pojęcie nierzetelności rozumiane jest w kontekście oceny rezultatu działania. Podstawowym kryterium stwierdzenia czy księgi rachunkowe są rzetelne jest ich stosunek do rzeczywistości. Księgi rzetelne powinny prawidłowo obrazować wszystkie zdarzenia go-

1 Ustawa z 29 sierpnia 1997 r. Ordynacja podatkowa, art. 3 pkt 4. 
spodarcze, które zaszły w przedsiębiorstwie i które są istotne z podatkowo prawnego punktu widzenia. Ustalenie rzetelności ksiąg to ustalenie faktów, a nie ocena prawna (Malinowski, 2006, s. 3). W celu orzeczenia o nierzetelności ksiąg, należy stwierdzić istnienie choćby jednego dowodu, który potwierdza zapis zdarzenia nieistniejącego, brak zapisu zdarzenia istniejącego lub wpis w księdze wielkości wyższej lub niższej niż wynika to ze zdarzenia, które zaszło w rzeczywistości (Dzwonkowski, 2010, s. 115).

Instytucja wadliwości, określana także nieprawidłowością formalną, ma mniejsze znaczenie. O ile punktem odniesienia nierzetelności jest rzeczywistość, o tyle w przypadku wadliwości są nim przepisy prawa odnoszące się do sposobu prowadzenia ksiąg. Wadliwość nie ma charakteru bezwzględnego. Zgodnie z zapisami Ordynacji podatkowej organ podatkowy uznaje księgi rachunkowe za dowód, nawet jeżeli są prowadzone wadliwie, pod warunkiem, że wadliwość ta nie ma istotnego znaczenia dla sprawy².

Jako że księgi rachunkowe stanowią podstawowe źródło danych niezbędnych dla prawidłowego obliczenia podstawy opodatkowania podatkiem dochodowym, stwierdzenie ich nieprawidłowości niesie za sobą daleko idące skutki. Zgodnie z zapisem Ordynacji podatkowej, organ podatkowy w razie niemożności określenia podstawy opodatkowania może dokonać jej oszacowania. Tego że określenie podstawy opodatkowania metodą szacunkową jest ostatecznością często określaną w doktrynie „złem koniecznym” (Olszowy, 1994, s. 62), dowodzi, że organ podatkowy powinien odstąpić od oszacowania, gdy dane wynikające $\mathrm{z}$ ksiąg podatkowych uzupełnione o inne dane zebrane w toku postępowania pozwalają na określenie podstawy opodatkowania ${ }^{3}$.

\section{Księgi rachunkowe a definicja podatku}

Istota ksiąg rachunkowych jako narzędzia pomocnego w ustalaniu podstawy opodatkowania w podatku dochodowym wynika z samego sensu podatku. Podatek definiowany jest jako pobranie dokonane w drodze przymusu przez władzę publiczną, którego zasadniczym celem jest pokrycie obciążeń publicznych i ich rozdzielenie według zdolności podatkowej obywateli (Gaudemet, Molinier, 2000, s. 407). W sensie ekonomicznym podatek jest formą przejęcia na rzecz państwa lub związku publicznoprawnego, od podmiotów im podporządkowanych, części przychodu, dochodu lub majątku tych podmiotów (Gomułowicz, Małecki, 2004, s. 126). Forma, tryb i zakres przejęcia dochodów podatkowych nie mogą być jednak arbitralne i muszą uwzględniać zdolność podatnika do poniesienia ciężaru podatkowego w taki sposób, aby nie niszczyć źródła opodatkowania. Niewątpliwie księgi rachunkowe są narzędziem jak najbardziej potrzebnym, gdyż ich celem, jeśli prowadzone są rzetelnie jest

2 „W przypadku stwierdzenia, że księgi podatkowe prowadzone są wadliwie i jeżeli wady te nie mają istotnego znaczenia dla sprawy, księgi takie mogą zostać uznane za dowód”. Wyrok WSA z 5.09.2006 r. Sygn. akt III SA/ Wa 2025/2006, Omega LEX 279065.

3 Nieprawidłowe prowadzenie ksiąg rachunkowych wiąże się także z odpowiedzialnością karną skarbową art. 61 Kodeksu karnego skarbowego. Por. Wilk, Zagrodnik, 2007, s. 280. 
ukazanie prawdziwego obrazu sytuacji finansowej przedsiębiorstwa, czyli także zdolności podatkowej.

Oprócz definicji zasadniczej podatku, w literaturze przedmiotu wskazuje się na cele, które podatek powinien realizować. W określeniu celów podatku można doszukiwać się elementów istoty ksiąg rachunkowych przez stwierdzenie siły oddziaływania podatku na obraz finansów przedsiębiorstwa.

\section{Rachunkowy i finansowy obraz podatku dochodowego}

Wskazanie znaczenia ksiąg rachunkowych wymaga ukazania podatku w sensie rachunkowym i finansowym, choć podatek sensu stricte nie jest kategorią rachunkową. Rozróżnianie pojęć wynika głównie z innego rozumienia istoty podatku. Do największych rozbieżności dochodzi właśnie w podatku dochodowym, a wynikają one z różnego uznawania przychodów i kosztów, także tych kosztów, które są konsekwencją podatków majątkowych i konsumpcyjnych (Wolińska, 1997, s. 96). O tym jak dalece prawidłowo ustalony wynik finansowy odbiega od wyniku podatkowego decyduje stan rozbieżności między zasadami rachunkowymi i podatkowymi, a rozbieżności te są skutkiem odmiennego charakteru roli i funkcji, jakie stoją przed systemem rachunkowości i systemem podatkowym. Znaczenie zobowiązań podatkowych wynika z wpływu prawa podatkowego na praktykę rachunkowości. Już w 1937 roku S. Skrzywan pisał: „,chcę (...) na podstawie faktów wziętych z codziennej praktyki wykazać, że czynnik podatkowy wywiera dziś decydujący wpływ na księgowość i bilanse przedsiębiorstw, powodując utożsamianie bilansu handlowego i bilansu podatkowego" (Skrzywan, 1937, s. 1-17).

Nauka rachunkowości nie definiuje pojęcia podatku. W literaturze z zakresu rachunkowości uwypukla się istotę podatku dochodowego, zakładając neutralność podatku od towarów i usług oraz całkowicie kosztowy charakter podatków lokalnych i innych zobowiązań publiczno-prawnych. Odmienne regulacje w prawie bilansowym i podatkowym powodują, że uwzględnienie w sprawozdaniu finansowym jedynie skutków ujęcia z tytułu podatku dochodowego, zgodnie z przepisami podatkowymi, doprowadziłoby do pominięcia istotnych zasobów kontrolowanych przez jednostkę i jej zobowiązań (Świderska, Więcław, 2009, rozdz. 14). Wynika stąd, że teoria rachunkowości nie definiuje podatku jako ciężaru i płatności, ale dostrzega obowiązkowy charakter zobowiązania podatkowego nie tylko w bieżącej działalności firmy, ale także jako zobowiązanie przyszłe. Konsekwencją tego jest ujęcie w bilansie nie tylko kwoty podatku, do zapłaty którego zobowiązane jest przedsiębiorstwo, ale także podatku odroczonego.

Zgodnie z teorią rachunkowości powstaje zjawisko alokacji podatku w czasie. Skutkiem tego obciążenie wyniku finansowego $\mathrm{z}$ tytułu podatku niekoniecznie równa się podatkom płaconym za ten okres. Podatek odroczony winien być ujmowany w rachunkowości zgodnie z jej zasadami. Nauka rachunkowości uzasadnia takie ujęcie podatku zasadą współmierności, która nakazuje ujmowanie kosztów na podstawie ich związku przyczynowo-skutkowego z wykazanymi w sprawozdaniu przychodami oraz zasadą memoriału stosowaną do liczenia 
przychodów i kosztów w przedsiębiorstwie (Hendriksen, van Breda, 2002, s. 701-703), z której wynika że wykazywany jest w tym samym okresie, co przyczyna jego powstania (różnica przejściowa w przychodach i kosztach) (Gabrusiewicz, Kamieniecka, 2007, s. 63-64).

\section{Księgi rachunkowe a istota podatku}

Konsekwencją istoty podatku w rachunkowości jest znaczenie ksiąg rachunkowych w szacowaniu podstawy opodatkowania podatkiem dochodowym. Jak wskazano wcześniej, jeżeli księgi rachunkowe są prowadzone rzetelnie i niewadliwie stanowią dowód tego, co wynika z zawartych w nich zapisów (Ordynacja podatkowa, art. $193 \S 1$ ). Rzetelność ksiąg w rozumieniu ordynacji podatkowej oznacza bezwzględny nakaz ewidencjonowania w księdze wszystkich wymaganych zdarzeń gospodarczych, wpływających na przychód, koszty, straty i zyski podatnika. „Za rzetelne uważane są księgi, jeżeli zawierają wszystkie fakty, będące przedmiotem wpisów do ksiąg, i to w całości zgodnie z prawdą. Przymiot rzetelności tracą te księgi, których zapisy nie odzwierciedlają stanu rzeczywistego. Nieodzwierciedlenie przez księgę stanu rzeczywistego może sprowadzać się do braku zapisów zdarzeń, które miały w rzeczywistości miejsce, oraz do ujęcia zdarzeń fikcyjnych, np. na podstawie tzw. pustych faktur"'.

Przydatność ksiąg rachunkowych do szacowania podstawy opodatkowania podatkiem dochodowym wynika także z punktu widzenia ich oceny. Według kryteriów zawartych w ordynacji podatkowej, księgi podlegają ocenie na płaszczyźnie podatkowej. Definicje rzetelności i niewadliwości zawarte są w ustawie i rodzą skutki w zakresie prawa podatkowego, natomiast księgi rachunkowe prowadzone na podstawie zapisów ustawy o rachunkowości (Ustawa o rachunkowości) mogą podlegać ocenie na dwóch różnych płaszczyznach. Obowiązek prowadzenia ksiąg rachunkowych nałożony został dla celów sprawozdawczości finansowej, tj. przedstawienia sytuacji finansowej podmiotu gospodarczego, a nie dla celów podatkowych - wymiaru zobowiązania podatkowego prawidłowej wysokości. W wyroku z 21.11.1996 roku NSA stwierdził ,niekwestionowaną zasadą polskiego prawa podatkowego jest, że obowiązek podatkowy określają ustawy. Zakres tego obowiązku nie może być kształtowany w oparciu o przepisy regulujące sposób dokumentowania operacji gospodarczych, czyli przepisy o rachunkowości”5. W innym wyroku NSA podkreślił, że „zapisy w księgach rachunkowych nie mogą rozstrzygać o tym, co i kiedy jest dochodem oraz kosztem uzyskania przychodu"6.

W orzecznictwie ugruntowany jest pogląd, że tylko przepisy prawa podatkowego decydują o uznaniu danego przysporzenia lub wydatku odpowiednio za przychód, dochód czy koszt uzyskania przychodów. Aby przepisy ustawy o rachunkowości wywierały skutki podatkowe,

4 Wyrok WSA w Gdańsku z 24.03.2011 r. sygn. Akt I SA/Gd 879/0.

5 Por. Wyrok NSA z 21.11.1996 r., SA/Rz 1149/95, za: Modzelewski, 1999.

6 Wyrok NSA z 2.04.1996 r. - SA/Ka 1405/95. 
w tym w zakresie kształtowania podstawy opodatkowania w podatku dochodowym, muszą istnieć przepisy prawa podatkowego, zapisy w ustawie o podatku dochodowym od osób prawnych, wyraźnie odsyłające wprost do konkretnych regulacji lub instytucji prawa bilansowego. W wyroku z 30 września 2015 roku WSA w Gdańsku sąd podkreślił, że aby uznać wydatek za koszt uzyskania przychodu w podatku dochodowym nie musi on jednocześnie spełniać kwalifikacji kosztu w rozumieniu przepisów ustawy o rachunkowości, a zapis ustawy o podatku dochodowym od osób prawnych ${ }^{7}$ odwołuje się wyłącznie do ujęcia kosztu w księgach rachunkowych ${ }^{8}$.

\section{Kategoria podatku a praktyka rachunkowości}

Praktyczny wymiar teorii rachunkowości ukazuje się jako podstawa odzwierciedlenia rzeczywistości. Teoria rachunkowości to bowiem zbiór pojęć, kategorii i zasad, dzięki którym możliwe jest przedstawienie rzeczywistości gospodarczej, czyli sytuacji majątkowo-finansowej konkretnego podmiotu gospodarczego. Teoria rachunkowości obejmuje zatem zbiór definicji i pojęć, koncepcji i zasad, metod oraz procedur, które służą prezentacji i objaśnianiu rzeczywistości gospodarczej. Zatem z jednej strony są to elementy składowe teorii rachunkowości, takie jak np. zasady lub metody, które pozwalają objaśniać rzeczywistość gospodarczą, z drugiej zaś to praktyka gospodarcza, która pozwala na formułowanie nowych koncepcji, hipotez i modeli (Remlein, 2014, s. 120-134).

Teorię rachunkowości należy rozpatrywać w dwóch aspektach jako:

- naukę uogólniającą praktyczne doświadczenia rachunkowości jako systemu ewidencji gospodarczej i badającą wszelkie problemy teoretyczne powstające w związku z jej funkcjonowaniem (Gmytrasiewicz, Peche, Świderska, 1980, s. 22);

- ogólną teorię rachunkowości rozumianą jako zbiór hipotez, koncepcji, modeli i teorii, które umożliwiają wyjaśnienie, ocenę i przewidywanie zjawisk praktyki rachunkowości oraz stanowiących punkt wyjścia do formułowania nowych koncepcji i procedur (Dobija, 2005, s. 232).

Wskazując na praktyczny wymiar teorii rachunkowości należy wskazać, za W. Brzezinem, następujące funkcje rachunkowości (Brzezin, 1998, s. 11-12):

- generalizującą, polegającą na odpowiednim usystematyzowaniu i połączeniu w logiczną całość odpowiednio uogólnionych twierdzeń w przekrojach przedmiotowych, podmiotowych, funkcjonalnych i metodologicznych,

- komunikatywną, sprowadzającą się do dostarczania informacji (pojęć ogólnych) w języku intersubiektywnie sensownym, tj. jednakowo zrozumiałym przez specjalistów z tej dziedziny wiedzy,

- predyktyczną, polegającą na badaniu zmieniającego się otoczenia rachunkowości i na tej podstawie prognozowanie zmian, jakie będę zachodzić w rachunkowości,

7 Dotyczy art. 15 ust.4e ustawy o podatku dochodowym od osób prawnych. t.j. Dz.U. z 2014 r. poz. 851

8 Wyrok WSA w Gdańsku z 30.09. 2015 r. (I SA/Gd 1032/15). 
- praktyczną, wyrażającą się stosowaniem „ustaleń teorii rachunkowości” w poszczególnych dziedzinach rachunkowości przez ich odpowiednią ogólność i niesprzeczność z twierdzeniami dyscyplin szczegółowych.

Należy podkreślić funkcję predyktyczną oraz praktyczną. Potwierdzają to także słowa A. Jarugowej: „rachunkowość jest nauką ze względu na swoją metodologię, natomiast ze względu na jej zorientowanie na cel jest nauką stosowaną" (Jarugowa, 1991, s. 12-13).

Przeprowadzone, w zarysie, studia literatury, potwierdziły, że wśród teoretyków brakuje zgodności w identyfikowaniu i określaniu przedmiotu nauki rachunkowości. Część z badaczy przyjmuje „rzeczowy” charakter przedmiotu nauki rachunkowości, sprowadzając go do określonej dziedziny przedmiotowej (księgowości). Druga grupa teoretyków (współczesnych) odchodzi od takiego ujęcia (rzeczowego) przedmiotu nauki rachunkowości na rzecz podejścia „badawczego”. Oznacza to, że przedmiotem nauki rachunkowości jest to, czym zajmują się naukowcy w tej dziedzinie. Takie postrzeganie przedmiotu nauki rachunkowości pozwala na szerszy zakres i większą różnorodność badań naukowych w tym obszarze.

Należy uwypuklić zatem, że rachunkowość nie może być oderwana od praktyki, zjawisk i procesów gospodarczych, co potwierdzają słowa J. Górskiego (1975, s. 7), że rachunkowość jest nauką praktyczną i nie ma nauki bez praktyki.

\section{Uwagi końcowe}

Istota i cechy podatku są niezmienne w każdym systemie finansowym. Jeżeli rzetelnie prowadzone księgi rachunkowe są obrazem finansów przedsiębiorstwa, to winno to mieć odzwierciedlenie w szacowaniu podstawy opodatkowania w podatku dochodowym.

W definiowaniu istoty podatków w finansach przedsiębiorstwa można zauważyć błąd, który polega na niedostrzeganiu podmiotowości firmy, jej organizacji. Jeśli cechą współczesnych czasów jest narastająca niepewność i zmienność, to w takich warunkach nie pozostaje nic innego (Iwin-Garzyńska, 2011, s. 117-133), jak uznać za błędne oderwanie podstawy wymiaru podatku dochodowego od obrazu finansów przedsiębiorstwa w księgach rachunkowych.

\section{Literatura}

Brzezin, W. (1998). Ogólna teoria rachunkowości. Częstochowa: Wydawnictwo Politechniki Częstochowskiej.

Dobija, M. (2005). Teoria rachunkowości w zarysie. Kraków: Wydawnictwo Akademii Ekonomicznej w Krakowie.

Dzwonkowski, H. (red.) (2010). Prawo podatkowe. Warszawa: Wydawnictwo C.H. Beck.

Dzwonkowski, H., Zgierski, Z. (2006). Procedury podatkowe. Warszawa: Difin.

Gabrusiewicz, W., Kamieniecka, M. (2007). MSR 12 Podatek dochodowy. Warszawa: Difin.

Gaudemet, P.M., Molinier, J. (2000). Finanse publiczne. Warszawa: PWE.

Gmytrasiewicz, M., Peche, T., Świderska, G. (1980). Teoretyczne podstawy rachunkowości. Warszawa: PWN.

Gomułowicz, A., Małecki, J. (2004). Podatki i prawo podatkowe. Warszawa: LexisNexis. 
Górski, J. (1975). Metody poznawcze rachunkowości. Warszawa: PWE.

Hendriksen, E.A., van Breda, M.F. (2002). Teoria rachunkowości. Warszawa: Wydawnictwo Naukowe PWN.

Iwin-Garzyńska, J. (2010). Szkice o kapitale i podatkach w istocie nauki finansów przedsiębiorstw. Warszawa: Difin.

Iwin-Garzyńska, J. (2011). Kapitał i podatki w nauce finansów przedsiębiorstw. Finanse, 4, 117-133.

Jarugowa, A. (1991). Niektóre wyznaczniki rozwoju rachunkowości. W: A. Jaruga (red.), Współczesne problemy rachunkowości. Warszawa: PWE.

Konstytucja Rzeczypospolitej Polskiej z dnia 2 kwietnia 1997 r. Dz.U.1997.78.483.

Malinowski, D.M. (2006). Badanie ksiąg podatkowych w kontroli i postępowaniu podatkowym. Przegląd Podatkowy, 9, 3-4.

Modzelewski, W. (red.) (1999). Komentarz do ustawy o podatku dochodowym, Instytut Studiów Podatkowych, Warszawa 1999.

Olszowy, W. (1994). Podejmowanie decyzji podatkowej i jej sądowa kontrola w Polsce. Łódź: Wydawnictwo Uniwersytetu Łódzkiego.

Remlein, M. (2014). Teoria a nauka rachunkowości. Studia Oeconomica Posnaniensia, 2 (4).

Skrzywan, S. (1937). Wplyw ustawodawstwa podatkowego na księowość i bilanse przedsiębiorstw oraz znaczenie gospodarcze i skutki tego wplywu (s. 1-17). Katowice, za: Gabrusiewicz, W., Kamieniecka, M. (2007). MSR 12 Podatek dochodowy. Warszawa: Difin.

Świderska, G.K., Więcław, W. (red.) (2009). Sprawozdanie finansowe wedtug polskich i międzynarodowych standardów rachunkowości. Warszawa: Difin.

Ustawa z dnia 29 sierpnia 1997 r. Ordynacja podatkowa, t.j. Dz.U. z 2005 r., nr 8, poz. 60 ze zm.

Ustawa z dnia 29 września 1994 r. o rachunkowości, t.j. Dz.U. z 2009 r., nr 152, poz. 1223 ze zm.

Wilk, J., Zagrodnik, J. (2007). Kodeks karny skarbowy. Komentarz. Warszawa: Wydawnictwo C.H. Beck.

Wolińska, E. (1997). Rachunkowość finansowa w świetle podatku dochodowego. Warszawa: FRRwP.

Wyrok NSA z dnia 21 listopada 1996 r., SA/Rz 1149/95.

Wyrok NSA z dnia 21 listopada1996 r., SA/Rz 1149/95, za: Modzelewski, W. (red.) (1999). Komentarz do ustawy o podatku dochodowym. Warszawa: Instytut Studiów Podatkowych.

Wyrok WSA w Gdańsku z dnia 24 marca 2011 r. sygn. Akt I SA/Gd 879/08, publ. Lex 786725.

Wyrok WSA w Gdańsku z dnia 30 września 2015 r. sygn. Akt I SA/Gd 1032/15.

Wyrok WSA w Warszawie z dnia 5 września 2006 r. sygn. akt III SA/Wa 2025/2006, Omega LEX 279065.

\title{
MEANING OF ACCOUNTING BOOKS IN DETERMINING THE TAX BASE FOR INCOME TAX
}

\begin{abstract}
Purpose - Accurate determination of the tax base for income tax requires the adequate tools, which include the accounting books.

Design/Methodology/approach - Methods of literature analysis In theory of economics, tax and accounting theory.

Findings - Presents essence of accounting books in calculating the tax base for income tax on the background of the theory of tax.

Originality/value - As a result of the research are shown the definitions of the tax in light of the science of finance and accounting and category of the reliability of accounting books.
\end{abstract}

Keywords: accounting books, income tax, reliability

\section{Cytowanie}

Iwin-Garzyńska, J. (2017). Znaczenie ksiąg rachunkowych w określaniu podstawy opodatkowania w podatku dochodowym. Finanse, Rynki Finansowe, Ubezpieczenia, 3 (87/2), 161-168. DOI: 10.18276/frfu.2017.87/2-14. 